\title{
MJN \\ KNOWLEDGE AND ATTITUDE OF NERGELA SMOKING AMONG ATTENDEE IN CAFÉ IN ERBIL CITY
}

\author{
Muhammad Aula, Kareem F. Aziz \\ College of Nursing, Hawler Medical University- Kurdistan Region, Iraq \\ *Corresponding Author's Email:drkareem2009@yahoo.com
}

\begin{abstract}
Nergela is a kind of tobacco smoking that depends on special instrument that is used to smoke specially made with tobacco that comes with different flavors. Assessment of knowledge and attitude of Nergela smokers regarding hazards of Nergila smoking are necessary to identify negative points. The aim of this study was to identify knowledge and attitudes of water pipe smoking among attendee in café and identify relationship between overall knowledge and socio demographic variables. Non-probability sample of 300 Nergela smokers, who attend cafés in Erbil city, were used. The researcher has developed the questionnaire format as the study instrument for data collection. Reliability and validity of the tool was determined through a panel of experts $(r=0.75)$. The SPSS program, version 23 was used to deal with data. $P$-value $\leq 0.05$ was considered significant. The study results revealed that most of water pipe smokers had fair knowledge and most of them had negative attitudes. More than half of the participants were within age group of 18-25 years. There were highly significant associations between marital status and residence of study sample with the overall knowledge at value 0.005 to 0.006 respectively. The participants had poor knowledge about the health risk of sharing water pipe smoking, and bad attitudes regarding the fruit flavor tobacco.
\end{abstract}

Keywords: Knowledge, Attitude and Practices, Water pipe, Smoking, Café

\section{INTRODUCTION}

Water pipe tobacco smoking is a form of tobacco consumption that utilizes a single or multi-stemmed instrument to smoke flavored or non-flavored tobacco, where smoke is designed to pass through water or other liquid before reaching the smoker. The Water pipe, also known as", "shisha" or "hookah", consists of a head or tobacco bowl in which tobacco is placed. There is a body, a water bowl, a hose and a mouthpiece as well. Charcoal is put on top of the tobacco-filled head, and is separated from the tobacco by a perforated aluminum foil sheet. The top of tobacco bowl is loaded with the charcoal lit, smokers in a hose, through which air goes into the charcoal. It produces heated air, which evokes charcoal combustion, so it passes through tobacco, which produces smoke aerosol and it heats up. The smoke goes through the water pipe body, bubbles through the water (or, on occasion, alcohol or soft drinks) in the bowl and is carried though the hose to the smokers. Some water pipes have multiple mouth pieces; others have a communal mouthpiece that is shared by all the smokers (WHO , 2015). Shisha smoking has been practiced in many Middle Eastern countries for more than three centuries. This broadening of shisha use could be partly due to the misconception that shisha smoking is less harmful and less addictive than cigarettes, or to a perceived positive image of shisha and smoking as being sociable (Maziak et al., 2004). Shisha smoking has become more accepted and widely used among young smokers, especially in university and high school students of both genders (Sandhu \& Babu, 2010). Water pipe smoking is gaining popularity nationwide, especially among urban youth, college students, and young professionals. Despite the growing popularity and increased adoption of state and local smoke free workplace laws, hookah bars remain largely unregulated. Some hookah smokers think that the practice less health hazard than smoking practices. So this is a problem for public health issues until evidence approved that hookah smoking contains same risks for health and also may cause many diseases as the same of smoking habit like lung 
cancer for example. (American Association of Lung, 2011). "Electric-hookah" or "Electric -shisha" or "hookah pens" are not water pipes, these are electronic nicotine delivery systems, that do not involve charcoal combustion; rather, a sweetened liquid, usually containing nicotine is electrically heated to create an aerosol that is then inhaled. Research is currently being done on these devices (WHO, 2015).

\section{RESEARCH METHODOLOGY}

\section{Design of the study}

A quantitatively designed descriptive crosssectional study was carried out to assess knowledge and attitude of water pipe smoking.

\section{Setting of the study}

The study was conducted in some selected in four geographical areas in Erbil city (north, east and west of). (Erbil Governorate, 2012).

\section{Time of the study}

The study was conducted during the period from $15^{\text {th }}$ Nov, 2015 to $15^{\text {th }}$ Nov, 2016. The data were collected from $5^{\text {th }} \mathrm{Feb} 2016$ to $5^{\text {th }}$ May 2016 in Erbil city, Kurdistan Region- Iraq.

\section{Administrative arrangements and ethical consideration approval}

Before the data collection, an official request was sent from College of Nursing/Hawler Medical University to take permission from General directorate of Health-Erbil/Ministry of Health and Ministry of Interior.

\section{Study population}

The target population was all water pipe smokers who were attendant at a café in Erbil city.

\section{Sampling}

A probability sample of 300 water pipe smokers who attend a café in Erbil city, who fulfilled the inclusion criteria and those who were available during the data collection.

\section{Inclusion criteria}

Water pipe smokers who gave consent to participate in the study were among the attendant of cafés in Erbil city.

\section{Exclusion criteria}

1. Any person who didn't want to participate in the study.

2. Cafés worker staff.

3. Non-water pipe smokers.

\section{Sample size estimation}

The sample size was calculated using the following statistical formula (Araoye, 2003):

Sample size $=\mathrm{Z} 2 \mathrm{pq} / \mathrm{d} 2$

$\mathrm{Z}=$ confident interval $95 \%$ (1.96)

$\mathrm{p}=$ prevalence $(0.19)$

$\mathrm{q}=(1-\mathrm{p})=(0.81)$

$\mathrm{d}=$ sampling error $(0.05)$

Sample size $=(1.96) 2 *(0.19) *(0.81) /(0.05) 2=237$

Notes: 0.19 is the average prevalence of water pipe smoking among adults in Arabic Countries, for getting more representative sample size the researcher selected 300 participants as a study sample.

\section{Methods of data collection and questionnaire}

Data were collected by using the questionnaire structure interview technique; researcher attended the cafés during the day and night from 8 P.M. to 11 P.M. and for 3 days in a week. Each day about 8-9 participants were interviewed. The researcher collected the data by face to face interviewing water pipe smokers using a constructed questionnaire format developed by researcher after reviewing the literature and spent about 15-20 minutes with each participant.

\section{Validity of the questionnaire}

Validity is the degree to which the study accurately reflects or assesses the specific concept that the researcher attempting to measure (Parahoo, 2014). The questionnaire has been validated by a panel of fourteen experts in different fields to review the content of questionnaire for its clarity and adequacy. A preliminary copy of the questionnaire was sent to each expert. The fourteen expert's responses were evaluated based on their agreements or disagreements. Reliability refers to the degree of consistency with which an instrument measures an attribute. It is a pointer of the ability of an instrument to produce similar scores on repeated testing occasions that occur under similar condition (Depoy \& Gitlin, 2015). Internal consistency, reliability was determined and measured through 
computation of person product moment correlation. The correlation coefficient was $(r=0.75)$ calculated for the reliability estimates out of the data which were gathered from 30 water pipe smokers in cafés in Erbil city. The correlation coefficient test was carried out to decide about the reliability of the instrument in terms of stability, consistency, accuracy and dependability to be used in different situations, as well as separate times.

\section{Statistical analysis}

The data were analyzed by using Statistical Package for the Social Sciences (SPSS) software for statistical analysis Version 23. The responds of the knowledge items were including two answers $(0=$ No and $1=$ Yes $)$. The calculation of overall levels of knowledge (10) items after recoding negative questions) was categorized to three groups of Poor knowledge's (0-3.33), Fair knowledge (3.34-6.67) and Good knowledge (6.68-10). The responds of the attitude items were including two answers ( $1=$ Agree, $2=$ Disagree and $3=$ Not decide). The calculation of overall levels of attitude (12 items) was categorized into three groups of Positive attitudes (1219.9), Negative attitude (20-27.9) and not decided (2836).

\section{Ethical considerations}

Before data collection, the ethical approval was obtained from ethical committee at College of Nursing/Hawler Medical University and a verbal agreement was obtained from water pipe smokers who participated in the study.

\section{RESULTS}

\section{Table 1: Socio-demographic characteristics of the study sample $(n=300)$}

Table 1 indicates that more than half of study samples were within age group $(18-25)$ years old which represented $183(61 \%)$, while the lowest age group was $(>41)$ years which represented $2(0.7 \%)$, about two-thirds $219(73.0 \%)$ of them were single. Less than half $147(49.0 \%)$ of them were Unemployed, while only $(17.3 \%)$ of them were employed. Most of them $278(92.7 \%)$ were the inhabitant in the city, more than one-third 116(38.7\%) were College and Institute graduated, only a few $7(2.3 \%)$ of them were Post graduate, most of them were not smoking cigarettes $(66.0 \%)$, and more than two third 254(84.7\%) were not having alcoholism.

\begin{tabular}{|c|c|c|c|}
\hline \multicolumn{2}{|c|}{$\begin{array}{l}\text { Socio-demographic } \\
\text { characteristic }\end{array}$} & \multirow{2}{*}{$\begin{array}{c}\mathbf{F} \\
18\end{array}$} & \multirow{2}{*}{$\begin{array}{c}\% \\
(6)\end{array}$} \\
\hline \multirow{5}{*}{$\begin{array}{l}\text { Age group / } \\
\text { years }\end{array}$} & $16-17$ & & \\
\hline & $18-25$ & 183 & $(61)$ \\
\hline & $26-33$ & 81 & $(27)$ \\
\hline & $34-41$ & 16 & $(5.3)$ \\
\hline & $>41$ & 2 & $(0.7)$ \\
\hline \multirow{2}{*}{\begin{tabular}{|l} 
Marital \\
status
\end{tabular}} & Single & 219 & (73) \\
\hline & Married & 81 & (27) \\
\hline \multirow[t]{3}{*}{ Occupation } & \begin{tabular}{|l|} 
Unemployed \\
\end{tabular} & 147 & $(49)$ \\
\hline & Student & 101 & $(33.7)$ \\
\hline & Employ & 52 & (17.3) \\
\hline \multirow[t]{2}{*}{ Residence } & City (Urban) & 278 & $(92.7)$ \\
\hline & Suburban & 22 & $(7.3)$ \\
\hline \multirow{5}{*}{$\begin{array}{l}\text { Education } \\
\text { level }\end{array}$} & \begin{tabular}{|l|} 
Illiterate \\
\end{tabular} & 14 & $(4.7)$ \\
\hline & primary & 52 & $(17.3)$ \\
\hline & Secondary & 111 & (37) \\
\hline & $\begin{array}{l}\text { College and } \\
\text { Institute } \\
\end{array}$ & 116 & $(38.7)$ \\
\hline & \begin{tabular}{|l|} 
Postgraduate \\
\end{tabular} & 7 & $(2.3)$ \\
\hline \multirow{2}{*}{$\begin{array}{l}\text { Cigarette } \\
\text { smoking }\end{array}$} & No & 198 & $(66)$ \\
\hline & Yes & 102 & (34) \\
\hline \multirow[t]{2}{*}{ Alcoholism } & No & 254 & $(84.7)$ \\
\hline & Yes & 46 & (15.3) \\
\hline
\end{tabular}

Table 2: Study sample Knowledge regarding Water pipe smoking $(n=300)$

\begin{tabular}{|c|c|c|c|c|}
\hline \multirow{2}{*}{ Knowledge aspect } & \multicolumn{2}{|c|}{ No } & \multicolumn{2}{|c|}{ Yes } \\
\hline & $\mathbf{F}$ & $\%$ & $\mathbf{F}$ & $\%$ \\
\hline 1. WPS is harmful for health. & 79 & 26.3 & 221 & 73.7 \\
\hline $\begin{array}{l}\text { 2. WPS is more dangerous than } \\
\text { cigarette smoking. }\end{array}$ & 123 & 41 & 177 & 59 \\
\hline $\begin{array}{l}\text { 3. WPS contains less nicotine } \\
\text { than cigarettes. }\end{array}$ & 190 & 63.3 & 110 & 36.7 \\
\hline $\begin{array}{l}\text { 4. WPS sharing can cause } \\
\text { communicable disease. }\end{array}$ & 154 & 51.3 & 146 & 48.7 \\
\hline $\begin{array}{l}\text { 5. Water in WP filters toxin } \\
\text { substances. }\end{array}$ & 197 & 65.7 & 103 & 34.3 \\
\hline $\begin{array}{l}\text { 6. WPS lead to cardio vascular } \\
\text { disease. }\end{array}$ & 138 & 46 & 162 & 54 \\
\hline 7. WPS leads to lung cancer. & 126 & 42 & 174 & 58 \\
\hline 8. Fruit flavor in WP have benefit. & 231 & 77 & 69 & 23 \\
\hline 9. WPS lead to dental problem. & 144 & 48 & 156 & 52 \\
\hline $\begin{array}{l}\text { 10. Water pipe smoking does } \\
\text { not irritate the bronchi }\end{array}$ & 187 & 62.3 & 113 & 37.7 \\
\hline
\end{tabular}


Table 2 illustrate that majority $221(73.7 \%$ ) of participants knew that water pipe smoking is harmful for health. $177(59 \%)$ of study samples had determined that water pipe smoking is more dangerous than cigarette smoking, more than half 190 (63.3\%) didn't inform that water pipe smoking contains less nicotine than cigarettes, more than half $154(51.3 \%)$ was not aware that water pipe smoking sharing can cause communicable disease 197 (65.7\%) didn't believe that water in water pipe smoking filters toxic substances, about 162 (54\%) perceived that water pipe smoking lead to cardiovascular disease, less than two third174 (58\%) expressed that water pipe smoking leads to lung cancer, more than two third $231(77 \%)$ said that Fruit flavor in WP didn't have benefit,156 (52\%) asserted that water pipe smoking leads to dental problem and only 187 $(62.3 \%)$ didn't give consent that water pipe smoking does not irritate the bronchi.

\section{Table 3: Study sample Attitude regarding Water pipe smoking $(n=300)$}

\begin{tabular}{|c|c|c|c|c|c|c|}
\hline \multirow{2}{*}{ Attitude aspect } & \multicolumn{2}{|c|}{ Agree } & \multicolumn{2}{|c|}{ Disagree } & \multicolumn{2}{|c|}{$* \mathbf{N D}$} \\
\hline & $\mathbf{F}$ & $\%$ & $\mathbf{F}$ & $\%$ & $\mathbf{F}$ & $\%$ \\
\hline $\begin{array}{l}\text { 1. WPS is acceptable by the society } \\
\text { rather than CS }\end{array}$ & 172 & 57.3 & 95 & 31.7 & 33 & 11 \\
\hline $\begin{array}{l}\text { 2. WPS represents a good chance to } \\
\text { meet friends }\end{array}$ & 178 & 59.3 & 89 & 29.7 & 33 & 11 \\
\hline $\begin{array}{l}\text { 3. My parents allow me to WPS at } \\
\text { home but not CS }\end{array}$ & 130 & 43.3 & 145 & 48.3 & 25 & 8.3 \\
\hline $\begin{array}{l}\text { 4. Smoking ofwater pipe relieves } \\
\text { stress and tension }\end{array}$ & 127 & 42.3 & 153 & 51 & 20 & 6.7 \\
\hline $\begin{array}{l}\text { 5. Smoking thewater pipe helps one } \\
\text { to relax }\end{array}$ & 147 & 49 & 136 & 45.3 & 17 & 5.7 \\
\hline $\begin{array}{l}\text { 6. Female may smoke WP but not } \\
\text { CS. }\end{array}$ & 98 & 32.7 & 172 & 57.3 & 30 & 10 \\
\hline $\begin{array}{l}\text { 7. WPS helps people stay thin and } \\
\text { cool }\end{array}$ & 61 & 20.3 & 206 & 68.7 & 33 & 11 \\
\hline 8. WPS is a sign of high social status & 52 & 17.3 & 220 & 73.3 & 28 & 9.3 \\
\hline 9. WPS is not as addictive. & 132 & 44 & 154 & 51.3 & 14 & 4.7 \\
\hline 10. WPS can quit easily. & 174 & 58 & 102 & 34 & 24 & 8 \\
\hline $\begin{array}{l}\text { 11. WPS calms me down when I feel } \\
\text { nervous }\end{array}$ & 161 & 53.7 & 110 & 36.7 & 29 & 9.7 \\
\hline $\begin{array}{l}\text { 12. My parents would not object my } \\
\text { smoking of Water pipe compared } \\
\text { to cigarettes }\end{array}$ & 174 & 58 & 93 & 31 & 33 & 11 \\
\hline
\end{tabular}

Table 3 shows that $172(57.3 \%)$ of participants thought that WPS is acceptable by the society rather than
CS, $178(59.3 \%)$ agreed that WPS represents a good chance to meet friends, less than half $145(48.3 \%)$ of participant's parents disagreed to smoke WP at home but not CS, other than half 153 (51\%) disagreed that Smoking of WP relieves stress and tension, fewer than half $147(49 \%)$ agreed that Smoking WP helps one to relax, $172(57.3 \%)$ disagreed that female may smoke WP but shouldn't CS, 154 (51.3\%) didn't thought that WPS is not as addictive, a large proportion 206 (68.7\%) didn't thought that WPS helps people stay thin and cool, more than half 174(58\%) believed that WPS can quit easily, more than two-third 220 (73.3\%) didn't believe that WPS is a sign of high social status, whenever $161(53.7 \%)$ reflected that WPS calm down when feel nervous. Only $174(58 \%)$ of participants said; his parents would not object WPS compared to CS.

\section{Table 4: Distribution of study sample according to the} level of knowledge

\begin{tabular}{|l|c|c|}
\hline Overall Knowledge & F & \% \\
\hline Poor(0-3.33) & 41 & $(13.7)$ \\
\hline Fair(3.34-6.67) & 171 & $(57)$ \\
\hline Good(6.68-10) & 88 & $(29.3)$ \\
\hline Total & $\mathbf{3 0 0}$ & $\mathbf{1 0 0} \%$ \\
\hline
\end{tabular}

Table 4 Distribution of study sample according to the level of knowledge. Table 4 shows that the highest percentage of study samples $171(57 \%)$ had a fair level of knowledge, $88(29.3 \%)$ were had a good level of knowledge, and only $41(13.7 \%)$ of them had a poor level of knowledge about water pipe smoking.

\section{Table 5: Overall Attitudes}

\begin{tabular}{|l|c|c|}
\hline Overall Attitude & F & \% \\
\hline $\begin{array}{l}\text { Positive attitude } \\
(12-19.9)\end{array}$ & 137 & 45.7 \\
\hline $\begin{array}{l}\text { Negative attitude } \\
(20-27.9)\end{array}$ & 153 & 51 \\
\hline $\begin{array}{l}\text { Not decided } \\
(28-36)\end{array}$ & 10 & 3.3 \\
\hline Total & $\mathbf{3 0 0}$ & $\mathbf{1 0 0} \%$ \\
\hline
\end{tabular}

Table 5 shows that the highest percentage of study sample 137(45.7\%) had a positive attitude towards water pipe smoking, 153(51\%) had a negative attitude, and only $10(3.3 \%)$ of them have not decided towards their attitude about water pipe smoking. 
Table 6: Relationship between socio-demographic characteristics of the study sample with their level of knowledge

\begin{tabular}{|c|c|c|c|c|c|c|c|c|}
\hline \multirow{3}{*}{\multicolumn{2}{|c|}{$\begin{array}{l}\text { Socio-demographic } \\
\text { characteristic }\end{array}$}} & \multicolumn{6}{|c|}{ Overall knowledge } & \multirow{3}{*}{$\begin{array}{c}* P- \\
\text { value }\end{array}$} \\
\hline & & \multicolumn{2}{|c|}{ Poor } & \multicolumn{2}{|c|}{ Fair } & \multicolumn{2}{|c|}{ Good } & \\
\hline & & \multirow{2}{*}{$\frac{F}{2}$} & \multirow{2}{*}{\begin{tabular}{|c|}
$\mathbf{\%}$ \\
$(11.1)$
\end{tabular}} & \multirow{2}{*}{$\begin{array}{c}\mathbf{F} \\
13\end{array}$} & \multirow{2}{*}{$\begin{array}{c}\mathbf{\%} \\
(72.2) \\
\end{array}$} & \multirow{2}{*}{$\mathbf{F}$} & \multirow{2}{*}{$\frac{\mathbf{\%}}{(16.7)}$} & \\
\hline \multirow{5}{*}{\begin{tabular}{|l} 
Age group \\
years
\end{tabular}} & $16-17$ & & & & & & & \multirow{5}{*}{$\begin{array}{l}0.303 \\
* * \mathbf{N S}\end{array}$} \\
\hline & $18-25$ & 22 & $(12.0)$ & 111 & $(60.7)$ & 50 & $(27.3)$ & \\
\hline & $26-33$ & 14 & $(17.3)$ & 41 & $(50.6)$ & 26 & $(32.1)$ & \\
\hline & $34-41$ & 3 & $(18.8)$ & 5 & $(31.3)$ & 8 & $(50.0)$ & \\
\hline & $p 41$ & 0 & $(0.0)$ & 1 & $(50.0)$ & 1 & $(50.0)$ & \\
\hline \multirow{2}{*}{$\begin{array}{l}\text { Marital } \\
\text { status }\end{array}$} & Single & 25 & $(11.4)$ & 137 & $(62.6)$ & 57 & $(26.0)$ & \multirow{2}{*}{$\begin{array}{c}0.005 \\
* * * \text { HS }\end{array}$} \\
\hline & Married & 16 & $(19.8)$ & 34 & $(42.0)$ & 31 & $(38.3)$ & \\
\hline \multirow[t]{2}{*}{ Residence } & City & 40 & $(14.4)$ & 163 & $(58.6)$ & 75 & $(27.0)$ & \multirow{2}{*}{$\begin{array}{c}0.006 \\
* * * \mathbf{H S}\end{array}$} \\
\hline & Urban & 1 & $(4.5)$ & 8 & $(36.4)$ & 13 & $(59.1)$ & \\
\hline \multirow[t]{3}{*}{ Occupation } & Unemployed & 24 & $(16.3)$ & 80 & $(54.4)$ & 43 & $(29.3)$ & \multirow{3}{*}{$\begin{array}{l}0.293 \\
* * \mathrm{NS}\end{array}$} \\
\hline & \begin{tabular}{|l|} 
Student \\
\end{tabular} & 12 & $(11.9)$ & 64 & $(63.4)$ & 25 & $(24.8)$ & \\
\hline & Employ & 5 & $(9.6)$ & 27 & $(51.9)$ & 20 & $(38.5)$ & \\
\hline \multirow{5}{*}{$\begin{array}{l}\text { Education } \\
\text { level }\end{array}$} & Illiterate & 2 & 14.3) & 10 & \begin{tabular}{|l}
$(71.4)$ \\
\end{tabular} & 2 & $(14.3)$ & \multirow{5}{*}{$\begin{array}{l}0.557 \\
* * \mathbf{N S}\end{array}$} \\
\hline & primary & 11 & $(21.2)$ & 24 & $(46.2)$ & 17 & $(32.7)$ & \\
\hline & Secondary & 14 & $(12.6)$ & 65 & $(58.6)$ & 32 & $(28.8)$ & \\
\hline & $\begin{array}{l}\text { College and } \\
\text { Institute } \\
\end{array}$ & 14 & (12.1) & 68 & $(58.6)$ & 34 & $(29.3)$ & \\
\hline & Post graduate & 0 & $(0.0)$ & 4 & $(57.1)$ & 3 & $(42.9)$ & \\
\hline \multirow{2}{*}{$\begin{array}{l}\text { Smoking } \\
\text { cigarette }\end{array}$} & No & 31 & $(15.7)$ & 114 & $(57.6)$ & 53 & $(26.8)$ & \multirow{2}{*}{$\begin{array}{l}0.220 \\
* * \mathbf{N S}\end{array}$} \\
\hline & Yes & 10 & $(9.8)$ & 57 & $(55.9)$ & 35 & $(34.3)$ & \\
\hline \begin{tabular}{|l|} 
Drinking \\
alcohol
\end{tabular} & No & 31 & $(12.2)$ & 143 & $(56.3)$ & 80 & $(31.5)$ & $\begin{array}{l}0.068 \\
* * N S\end{array}$ \\
\hline
\end{tabular}

Table 6 shows that there was a statistically significant association between marital status and residence of study samples with overall knowledge of study sample about water pipe smoking $(P$ value $\leq 0.05)$. While there was no statistically significant association between their age, occupation, education level, smoking a cigarette and drinking alcohol with overall knowledge of study sample about water pipe smoking ( $p$-value $>0.05$ ).

\section{DISCUSSION}

The finding of the study revealed that more than half of study samples were within age group (18-25) years old which represent $(61 \%)$. The finding of the study seems to be in agreement with Smith-Simone et al., (2008), a study conducted in Al-Hassa, Saudi Arabia among 201 male and female gender, found that most of the participants were young adults between age (1-25). The result of the current study showed that the entire study sample was male. This is congruent with the study conducted by Karimy et al., (2013) in city of Iran among
400 male students. It showed similar results with the work developed by Shaikh et al., (2008) in a descriptive cross sectional study among 202 males. But this result was in disagreement with Mirahmadizadeh \& Nakhaee, (2008) who conducted a research in rural areas of Southern Iran where all the study samples were female. As per my opinion; this is related to culture and social issue in our region where there is observation regarding the female who smoke water pipe or Cigarette. Regarding Marital status more than two-thirds (73.0\%) of the study, the sample was single. A quite similar finding has been reported by Doski \& Ahmed, (2015), which was conducted in all venues of cafes and restaurants located geographically in Erbil city, who found that $(72.6 \%)$ of study samples were male. A crosssectional descriptive study of a 150 sample of Iraqi male college students aged $\geq 18$ years in the College of Medical and Health Technology, Baghdad who found most of the study samples were single. The study showed that $(49 \%)$ of the samples were unemployed. The finding of our study agrees with Mohammed, (2013) that study conducted in Waterloo, Ontario. Canada has 342 participants, who found that most of the study samples were unemployed. Most of the study samples $(92.7 \%)$ were from the city may be due to the fact that our study focused on the center of Erbil city. The finding of the study agrees with the study of Burhan, (2012) that was conducted in sulaimania who found that majority (78\%) of the participants among 100 people were from the city (urban). More than one-third $(38.7 \%)$ of study samples were graduated in College and Institute. The finding of study agrees with Jawad et al., (2013), that study was conducted in the UK among 2213 participants, who found most of the participants (59.9\%) were undergraduates. But this is in contrast with the study conducted by (Martin et al., 2013) who found most of the study samples $(69 \%)$ were not uneducated (illiterate). Regarding cigarette smoking, most of the study samples $(66.0 \%)$ were not smoking cigarettes. The result strongly agrees with Grinberg \& Goodwin (2016), who found that $(66.8 \%)$ of the study sample among 3459-lifetime were water pipe users and not cigarette smokers. But this was disagreed with the finding of the study done by Jawad et al., (2013), who found that most of the participants $(65.8 \%)$ never tried cigarette smoking. More than two third $(84.7 \%)$ of the study samples were not alcoholism. This is related to two factors. One: Drinking alcohol in our culture is not accepted as a normal phenomenon because it is taboo in our religion. Second: the participants may not be truthful or trustful with us. But a study disagreed with the study 
conducted in the US among college student where (77.9\%) hookah users were addicted to alcoholism (Heinz et al., 2013).This study revealed majority $(73.7 \%)$ of participants knew that water pipe smoking is harmful to health. A quite similar finding has been reported by (Abughosh et al., 2012) among students in one US University who found that $(67.5 \%)$ students believed that water pipe smoking is hazardous to health. In our present study, about $(57.3 \%)$ of participants thought that water pipe smoking is acceptable by the society rather than Cigarette smoking. A quite similar finding has been reported by Amin et al., (2010) who found that $(52.1 \%)$ of participants thought that water pipe smoking is acceptable by the society rather than Cigarette smoking. The finding of our study shows that $(57.3 \%)$ of participants disagreed that female may smoke water pipe but not Cigarette smoking. According to the study Mansour et al., (2015) found that most of the study samples disagreed to marry a woman or a man smoker. But Amin et al., (2010) found that (46.5\%) believed that women smoking water pipe are odds as that smoking Cigarette. The finding of the study is an agreement with the study of Amin et al., (2010), who found that $(76.1 \%)$ of study samples indicated that meeting friends and family is the primary motives for water pipe smoking. The finding of this study is congruent with Ramji et al., (2015), who found that $(79 \%)$ of study samples believed that water pipe smoking more likely to have parental approval than a cigarette. The finding of the study is in contrast with kakodkar \& Bansal (2013), who found that (75\%) of study sample's parent didn't accept to smoke water pipe.

\section{CONCLUSION}

Water pipe smoking was more prevalent among the age group 18-25 and between institute and university level of study sample. The overall knowledge of the study sample was poor especially about the health risk of water pipe smoking. There was a false belief that the tobacco contains healthy fruits and thus smoking is beneficial for health. The results of this study confirmed negative and bad attitudes that water pipe smoking was acceptable to the society and parent. There was a highly significant association between the marital status and the overall knowledge of study sample. There was a highly significant association between the residence and the overall knowledge of study sample as well.

\section{RECOMMENDATIONS}

Develop an educational program for people early in adolescence stage, especially since the age of 18 years, and activate the role of the medical related organization in spreading health awareness regarding this potentially harmful activity in the community. Increase in both tax and price measures on water pipe tobacco and water pipe products Given the prevalence of misinformation surrounding the health dangers of water pipe tobacco smoking, specific education and training must be included in wider tobacco education and public awareness programmers implemented by Parties. The role of mass media can also assist by disseminating the messages of quitting smoking in the whole community

\section{LIMITATION}

There are some limitations of the study as some of them refused to participate in the study to end of time and others have not sufficient time to participate and some others left the process of collecting the data in the beginning.

\section{REFERENCES}

Abughosh, S., Wu, I.H., Rajan, S., Peters, R.J. \& Essien, E.J. (2012).Water pipe smoking among students in one US university: predictors of an intention to quit. Journal of American College Health, 60(7), pp 528-535.

American Lung Association. (2011). Hookah smoking: a growing threat to public health. Smoke free Communities Project. Retrieved from:http://www.lung.org/assets/documents/tobacco/hookah-policy-brief-updated.pdf.

Amin, T.T., Amr,M., Zaza, B.O. \& Suleman,W. (2010). Harm Perception, Attitudes and Predictors of Waterpipe (Shisha) Smoking among Secondary School Adolescents in Al-Hassa, Saudi Arabia. Asian Pacific journal of cancer prevention, 11(2), pp 293-30.

Araoye, M.O.(2003). Research Methodology with Statistics for Health and Social science. $1^{\text {st }}$ edition. Nathadex Publisher, Irion.

Burhan, B. (2012).Knowledge of adolescents regarding hookah smoking in slemania city. Thesis in Nursing. Sulaimani University, Iraq. 
Depoy, E. \& Gitlin, L. (2015). Introduction to Research. $5^{\text {th }}$ Edition. Mosby, US.

Doski, N, A. \& Ahmad,S.M.(2016). Awareness of hookah smokers regarding it's harmfulness among attendee of cafes in Erbil city. Zanco Journal of Medical Sciences, 20(2), pp 1361-1367.

Erbil Governorate. (2012) Retrieved from:http://www.hawlergov.org/en/page.php?id=1329120973

Grinberg, A. \& Goodwin, R.D. (2016). Prevalence and correlates of hookah use: a nationally representative sample of US adults ages 18-40 years old. The Americanjournal of drug and alcohol abuse, 42(5), pp 567-576.

Heinz, A.J., Giedgowd, G. E., Crane, N.A., Veilleux, J.C., Conrad,M., Braun, A.R., Olejarska, N.A. \& Kassel, J.D. (2013). A comprehensive examination of hookah smoking in college students: Use patterns and contexts, social norms and attitudes, harm perception, psychological correlates and co-occurring substance use. Addictive Behaviors, 38 (2013), pp 2751-2760.

Jawad, M., McEwen, A., McNeill, A. \& Shahab, L. (2013). To what extent should water pipe tobacco smoking become a public health priority? Addiction, 108(11), pp 1873-1884.

Kakodkar, P.V. \& Bansal, S.S. (2013). Hookah smoking: characteristics, behavior and perceptions of youth smokers in Pune, India. Asian Pacific Journal of Cancer Prevention, 14(7), pp 4319-4323.

Karimy, M., Niknami, S., Hidarnia, A., Hajizadeh, E. \& Shamsi, M. (2013). Personal Attitudes, Risk Perception and Perceived Vulnerability toward Water Pipe Smoking among Male Students in Zarandieh. Health Education and health promotion, 1 (2), pp 47-59.

Mansour, M.A.M., Youssef, H.A.M., Mawajdeh,N.A.A. \& Ayasreh, I.R.A.(2015). Awareness, Attitude and Practice of Smoking among Medical Sciences\& Non-Medical Sciences Students at Taif University: Comparative Study. International Journal of Science and Research, 4(1), pp 255-264.

Martin, R., Safaee, S.D., Somsamouth, K., Mounivong, B., Sinclair, R., Bansal, S. \& Singh, P.N.( 2013). Pilot study and research of change behaviors among pipe smokers of rural Lao PDR: focusing on infectious disease epidemiology. International journal of environmental research and public health, 10(6), pp 2120-2132.

Maziak, W., Ward, K.D., Soweid, R.A. \& Eissenberg, T. (2004). Tobacco smoking using a water pipe: a re-emerging strain in a global epidemic. Tobacco control, 13(4), pp 327-333.

Mirahmadizadeh, A. \& Nakhaee, N. (2008). Prevalence of Water pipe Smoking among Rural Pregnant Women in Southern Iran. Medical principal and practice, 17, pp 435-439.

Mohammed, H.T.(2013). The Efficacy of Viewing Health Warnings on Shisha Smoking among Shisha Smokers. Retrieved from:https://uwspace.uwaterloo.ca/bitstream/handle/10012/7419/Mohammed_HebaTallah. pdf?sequence $=1$.

Parahoo, K. (2014). Nursing research: principles, process and issues. $3^{\text {rd }}$ edition, Palgrave Macmillan, England.

Ramji, R., Arnetz, J., Nilsson, M., Jamil, H., Norström, F., Maziak, W., Wiklund, Y. \& Arnetz, B. (2015).Limiting of water pipe smoking use among young people in Northern Sweden: a survey of use aspects of risk factors knowledge, and other factors of environment. BMC research notes, 8(1), p 1.

Sandhu, S.V. \& Babu, N.C. (2010). Hookah hook ups: an insight. Journal of International Oral Health, 2, pp 21-26.

Shaikh, R.B.,Vijayaraghavan, N., Sulaiman, A.S., Kazi, S. \& Shafi, M.S. (2008).The acute effects of waterpipe smoking on the cardiovascular and respiratory systems. Journal of Preventive Medicine and Hygiene, 49(3), pp 101-107.

Smith-Simone, S., Maziak, W., Ward, K.D. \& Eissenberg, T.(2008).Waterpipe tobacco smoking: knowledge, attitudes, beliefs, and behavior in two U.S. samples. Nicotine \& Tobacco Research, 10(2), pp 393-398.

World Health Organisation. (2015). Study Group on Tobacco Product Regulation, Advisory note: Wastepipe tobacco smoking: health hazards affecting, study needs and suggestion trends for organization. Retrieved from: http://www.who.int/tobacco/global_interaction/tobreg/Waterpipe\%20recommendation_Final.pdf. 